\title{
COMMENTS
}

\section{Procedural Injury Standing after Lujan $v$ Defenders of Wildlife}

\author{
Christopher T. Burt $\dagger$
}

Imagine that a federal agency approves the construction of a dam that will submerge the habitat of an endangered species of beaver. A nearby resident frequently makes camping trips to this threatened area and particularly enjoys observing the beaver in its native environment. Upset that the federal project will ruin his camping opportunities as well as endanger the beaver population, the camper decides to sue the federal agency to stop the project. The basis for his suit is the failure of the federal agency to prepare an Environmental Impact Statement ("EIS") before approving the project, as required by law. ${ }^{1}$ Before the camper can get into court, however, he must meet the jurisdictional requirements of standing.

At a minimum, a litigant must show three things in order to have standing to sue: (1) that he has suffered an "injury in fact"; (2) that the injury is fairly traceable to the challenged action of the defendant; and (3) that it is likely that a favorable decision will fully redress the injury. ${ }^{2}$ In the above example, the camper

† A.B. 1992, The University of Chicago; J.D. Candidate 1995, The University of Chicago.

1 The National Environmental Policy Act ("NEPA") requires agencies to "include lan EIS] in every recommendation or report on ... major Federal actions significantly affecting the quality of the human environment." 42 USC \& 4332(2)(C) (1988).

2 See, for example, Lujan $v$ Defenders of Wildlife, 112 S Ct 2130, 2136 (1992). These three requirements are derived from Article III of the Constitution, which limits the judicial power to "Cases" and "Controversies." US Const, Art III, § 2. They must be shown "at a minimum" because prudential requirements of standing might also limit plaintiffs. 
cannot satisfy this last criterion, the redressability requirement, because it will be impossible for him to prove that a favorable action by the court (that is, an order directing the agency to prepare an EIS) will prevent the environmental harm that he fears. After all, even if forced to prepare the EIS, the agency might still conclude that the benefits of the dam outweigh its impact on the environment and thus allow the dam construction to proceed. Because he would be unable to show that an EIS would prevent the damage, the camper would not have standing to sue.

Enter the concept of procedural injury. A procedural injury occurs when an agency fails to follow a legally required procedure, such as the preparation of an EIS, and this failure increases the risk of future harm to some party. ${ }^{3}$ For a given plaintiff, the consequences of an agency's failure to follow a procedure are necessarily ambiguous since the agency might have reached the same result even if it had followed the correct procedure. Because procedural plaintiffs are never able to show that adherence to procedure will definitely avert subsequent harm, they are always unable to meet the redressability requirement of standing.

In Lujan $v$ Defenders of Wildlife, the Supreme Court suggested in a footnote that the "normal standards of redressability" should not apply to procedural injury plaintiffs. ${ }^{4}$ The precedential value of the Lujan approach to procedural injuries is questionable. First, the apparent removal of the "normal" redressability requirement contradicts the body of the Lujan opinion, which maintained that redressability is part of the "irreducible constitutional minimum" of standing. ${ }^{5}$ At no point in the opinion did the Court provide a reason for treating procedural injuries differently from other injuries. Second, the passage in Lujan concerning procedural injuries is only dicta. The Court denied standing to the plaintiffs in Lujan because it found that they failed the injury-in-fact test as well as the redressability requirement; therefore, a lower redressibility requirement alone would not have benefited them. The footnote concerns only those

See text accompanying notes 19-22.

${ }^{3}$ See text accompanying notes $23-25$ for a more detailed description of procedural injuries.

412 S Ct 2130,2142 n 7 (1992).

5 See id at 2136. 
cases where the plaintiff has a concrete interest but cannot prove redressability. ${ }^{6}$

Courts have used different methods to assess standing in procedural injury cases. ${ }^{7}$ This Comment addresses these various approaches to procedural injury standing and argues for a new analysis that would give procedural plaintiffs standing while retaining the result of Lujan. Section I provides a brief overview of the current standing doctrine and presents the problem this doctrine poses for procedural injuries. Section II outlines possible approaches to procedural injury cases, evaluates these approaches in the wake of Lujan, and argues that the redressability requirement should remain in place for procedural injuries. This Comment ultimately argues that injuries to opportunity, or increased risks of future harm, should be treated as injuries in fact as long as the plaintiff has a concrete interest at stake.

\section{THE STANDING REQUIREMENTS}

Justice Douglas aptly characterized the ambiguity that has traditionally surrounded the law of standing when he warned in 1970 that "[g]eneralizations about standing to sue are largely worthless as such." Although the doctrine of standing has undergone many changes in recent years, ${ }^{9}$ the Court has embraced the injury-in-fact, causation, and redressability requirements as "the irreducible constitutional minimum of standing," which in turn is an "essential and unchanging" part of the constitutional requirement that courts hear only cases or controversies. ${ }^{10}$ This Section explains these well-entrenched elements of current stand-

B See id at $2142 \mathrm{n} 7$ ("The person who has been accorded a procedural right to protect his concrete interests can assert that right without meeting all the standards for normal requirements of redressability .....) (emphasis added).

7 These various means will be discussed in Section II. The four chief methods are the following: (1) characterizing procedural injuries as an increased risk of future injury that occurs when agencies fail to follow procedures; (2) keeping the three constitutional standing requirements (including the redressability requirement) for procedural injuries; (3) treating governmental violations of procedure as sufficient in themselves to form the basis of standing; and (4) using the "informational injury" category to evaluate procedural violations.

${ }^{8}$ Association of Data Processing Service Organizations, Inc. $v$ Camp, 397 US 150, 151 (1970). More recently, Justice Rehnquist stated that "the concept of "Article III standing' has not been defined with complete consistency ...." Valley Forge Christian College $v$ Americans United for Separation of Church and State, 454 US 464, 475 (1982).

9 For an elaboration of the recent history of standing doctrine, see Cass R. Sunstein, What's Standing after Lujan? Of Citizen Suits, "Injuries," and Article III, 91 Mich L Rev 163, 183-97 (1992).

10 Lujan, 112 S Ct at 2136. 
ing jurisprudence as well as the "prudential" standing requirements, and illustrates the various problems procedural plaintiffs face in meeting these criteria.

\section{A. The Constitutional and Prudential Limitations}

Article III of the United States Constitution limits the "Judicial Power" of the United States to "Cases" and "Controversies." The Supreme Court has interpreted Article III to impose a "standing" requirement that restricts the jurisdiction of federal courts to those cases where, at an "irreducible minimum," it is shown that (1) the plaintiff has suffered an "injury in fact"-that is, an invasion of a legally protected interest that is "concrete and particularized" and "actual or imminent," not "conjectural" or "hypothetical"; (2) the plaintiff's injury is fairly traceable to the challenged action of the defendant and not the result of the independent action of some third party not before the court; and (3) it is likely, as opposed to merely speculative, that a favorable decision will redress the injury. ${ }^{12}$ These three elements are the "constitutional" requirements of standing.

The rationales offered for the constitutional requirements are varied and sometimes conflicting. ${ }^{13}$ One purpose is to ensure a "concrete adverseness[,] which sharpens the presentation of issues"; ${ }^{14}$ without litigants who care deeply about the case, the courts may reach an improper outcome. A second justification is to prevent litigants who have only a tangential interest in an issue from binding parties with a more direct interest; the "ideal of self-determination" requires a personal stake in the outcome. ${ }^{15} \mathrm{~A}$ third purpose is the prohibition on advisory opinions; judicial rulings that do not impact the parties are "bound to move in an unreal atmosphere." ${ }^{" 16}$ Courts need a concrete controversy before them in order to fully assess the consequences of their decisions for future litigants. Finally, Justice Scalia has consistently argued that standing serves a separation-of-powers function. ${ }^{17}$ Injuries that are not personal to the plaintiff are better

1 US Const, Art III, § 2.

12 Lujan, $112 \mathrm{~S} \mathrm{Ct}$ at 2136.

${ }^{13}$ See generally William A. Fletcher, The Structure of Standing, 98 Yale L J 221, 222-23 (1988); Comment, No Generalized Grievances: The "Law of Rules" Approach to Standing, 19 Ohio N U L Rev 927, 929-31 (1993).

${ }^{14}$ Baker v Carr, 369 US 186, 204 (1962).

15 See Lea Brilmayer, The Jurisprudence of Article III: Perspectives on the "Case or Controversy" Requirement, 93 Harv L Rev 297, 311 (1979).

${ }^{16}$ Felix Frankfurter, A Note on Advisory Opinions, 37 Harv L Rev 1002, 1006 (1924).

${ }^{17}$ See Antonin Scalia, The Doctrine of Standing as an Essential Element of the Sepa- 
redressed through the political process; rules of standing keep such matters out of the courts. ${ }^{18}$ These justifications reinforce the importance of the standing requirements, including redressability. They furnish reasons to retain the "normal" redressability requirement for plaintiffs alleging procedural injuries.

In addition to constitutional limitations, the Court has erected "prudential" barriers to judicial standing. The key prudential limitation is that "the interest sought to be protected by the complainant is arguably within the zone of interest sought to be protected or regulated by the statute or constitutional guarantee in question." ${ }^{\text {"19 }}$ A plaintiff meets this "zone of interest" test if it can "reasonably be assumed that Congress intended to permit the suit." Because such an intention can be established by a simple statement on the part of Congress to that effect, the zone-ofinterest test is easily satisfied in practice. In fact, the Court has only once denied standing on this ground. ${ }^{21}$ This Comment, therefore, will focus on the constitutional requirements, which after Lujan Congress cannot bypass. ${ }^{22}$

\section{B. The Constitutional Problem Posed by Procedural Injuries}

A procedural injury occurs when a federal agency fails to follow a required procedure and then acts to harm an interest of the plaintiff. If the agency had followed the procedure, it might never have taken the subsequent harmful action. For example,

ration of Powers, 17 Suffolk U L Rev 881 (1983); Lujan, 112 S Ct at 2136 (Scalia for the majority) (case or controversy requirement is the "Constitution's central mechanism of separation of powers"); id at 2144-45 (concrete injury requirement is "a principle fundamental to the separate and distinct constitutional role of the Third Branch").

IB See Lujan, $112 \mathrm{~S} \mathrm{Ct}$ at 2145 ("Vindicating the public interest . . . is the function of Congress and the Chief Executive."); Scalia, 17 Suffolk U L Rev at 884-97.

${ }^{19}$ Ass'n of Data Processing Service Organizations, Inc. $v$ Camp, 397 US 150, 153 (1970). Some of the other prudential limitations prevent the adjudication of generalized grievances and prohibit litigants from asserting the legal rights of another. See Warth $v$ Seldin, 422 US 490, 499 (1975). These limitations are redundant given the current constitutional requirements: the injury-in-fact requirement assures that the plaintiff's injury is concrete (not shared by the general public), see Lujan, $112 \mathrm{~S} \mathrm{Ct}$ at 2143, and that the plaintiff is "himself among the injured," id at 2137, quoting Sierra Club $v$ Morton, 405 US 727, 735 (1972).

${ }^{20}$ Clarke $v$ Securities Industry Ass'n, 479 US 388, 399 (1987). See also Fletcher, 98 Yale $\mathrm{L} J$ at 252 (cited in note 13) ("II]f Congress explicitly confers standing on [ ] a plaintiff, then the Court's 'prudential' hesitation is overcome.").

21 See Air Courier Conference of America $v$ American Postal Workers Union, 498 US 517 (1991).

22 See Lujan, $112 \mathrm{~S} \mathrm{Ct}$ at 2145-46 (stating that Congress cannot create new injuries in fact unless the injuries are concrete, as required by Article III). 
federal approval of the dam in the hypothetical case above injures the camper's interests in hiking and observing beavers. Because the dam was approved without the benefit of an EIS, and because an EIS might have led the agency to reject the dam proposal, the camper suffered a procedural injury. The agency ignored a procedure that might have prevented the substantive injury to the camper's recreational and aesthetic interests. ${ }^{23}$

A "procedural harm" is really an increased chance that there will be substantive harm in the future. Procedural and substantive harms are "two sides of a single coin: It is the alleged procedural failure in the EIS that 'create[s] a risk that environmental impact will be overlooked' (in the future)."24 Procedural harms, then, are probabilistic harms; they "inflict" a greater chance of future substantive injury. ${ }^{25}$

Procedural injury standing enables parties to reduce the chance of substantive harm by challenging procedural flaws that increase the risk of such harm. If courts grant standing in these circumstances, plaintiffs can force an agency to follow the proper procedure in the hope of changing the agency's ultimate course of action. Although a successful challenge to an agency procedure will not necessarily alter the agency's ultimate decision, such suits reduce the chance of an improper outcome and ensure that procedural errors do not remain unreviewable. Thus, requiring the federal agency to prepare an EIS will not necessarily prevent the agency from approving the dam; it will merely force the agency to consider the impacts of the dam on the endangered beaver and on the plaintiff's camping opportunities before proceeding. ${ }^{26}$ Without procedural standing, the camper may never be able to get the agency to consider environmental impacts.

Parties who have suffered procedural injuries often find it difficult to meet the injury-in-fact and redressability requirements. Plaintiffs may have trouble proving that their injuries are

${ }^{23}$ Lujan cites a very similar example to illustrate an instance of procedural injury where the plaintiff would have standing. See id at 2142-43 $\mathrm{n} 7$.

24 Idaho Conservation League v Mumma, 956 F2d 1508, 1514 (9th Cir 1992), quoting Oregon Environmental Council v Kunzman, 817 F2d 484, 491 (9th Cir 1987).

${ }_{25}$ See Sierra Club v Marsh, 872 F2d 497, 500 (1st Cir 1989). In this case, then-Judge Breyer clarified that the underlying harm in procedural injury cases is not the "harm to procedure," but the increased risk of substantive harm (to the environment, for example) that occurs when procedures are not followed.

${ }^{26}$ In fact, NEPA imposes no substantive requirements on agencies; the EIS requirement was designed to assure well-informed decisions without mandating particular results. "NEPA requires no more" than that agencies consider environmental consequences. Stryker's Bay Neighborhood Council, Inc. v Karlen, 444 US 223, 228 (1980). 
"imminent" or "concrete"; if so, they cannot establish injury in fact. ${ }^{27}$ For example, the camper's injury is arguably neither imminent (the dam may not be completed for years) nor concrete (the interest in the government preparing an EIS is simply an interest in the execution of the laws and thus shared by the general public). Procedural plaintiffs will necessarily have difficulty showing imminence because the ultimate substantive harm they seek to prevent will occur, if at all, at some time in the future. Procedural plaintiffs have difficulty satisfying the redressability criterion because adherence to procedures redresses the increased risk of future injury, but does not guarantee that future injury will not occur. The relief procedural plaintiffs seek can never redress the substantive injury itself-thus, if the courts look only to the substantive harm, procedural plaintiffs will never be able to meet the redressability requirement.

If violations of procedure achieve the status of injuries in fact, plaintiffs will have no problem meeting the redressability and causation requirements. ${ }^{28}$ This is because the failure to follow procedures would be considered the "cause" of an increased risk of future substantive injury, which is redressed when agencies follow required procedures. The redressability inquiry, then, turns upon the characterization of the injury. ${ }^{29}$ If procedural injuries are characterized as increased risks of future substantive harm, the redressability and causation difficulties disappear. The only remaining hurdle to standing is the injury-in-fact requirement, under which cognizable injuries must be concrete. Lujan raises the question whether procedural injuries can ever be concrete, or whether they are merely nonconcrete, "generally available grievance[s] about government." 30 If plaintiffs are ever to

27 The injury-in-fact test requires that the injury be both imminent and concrete. See text accompanying note 12. In this context, "concrete" means "not shared by the general public." See Lujan, $112 \mathrm{~S}$ Ct at 2143 n 8.

${ }^{28}$ The redressability and causation requirements are closely related; most procedural injury plaintiffs face both redressibility and causation problems. It may well be, for example, that an increased risk of substantive injury does not "cause" that injury for standing purposes. The failure to prepare an EIS does not "cause" environmental harm if the agency would have approved dam construction even with an EIS. In most cases, plaintiffs either meet, or fail to meet, both requirements. See Note, Standing to Sue: A Brief Overview of Current Standing Doctrine, 71 BU L Rev 667, 674-77 (1991). See also Richard J. Pierce, Jr., Sidney A. Shapiro, and Paul R. Verkuil, Administrative Law and Process $\S 5.4 .6$ at 144-50 (Foundation, $2 \mathrm{~d}$ ed 1992). This Comment focuses on the redressability requirement out of convenience; the analysis under the causation requirement would be much the same.

${ }^{29}$ See Sunstein, 91 Mich L Rev at 202-05, 207 (cited in note 9).

30 Lujan, $112 \mathrm{~S} \mathrm{Ct}$ at 2143. The Court held that a statute that gave all citizens the 
have standing to challenge procedural errors, they must find a way to characterize their injuries as concrete.

\section{Solutions to the Procedural InJURy Problem}

Courts and commentators have suggested several methods by which procedural plaintiffs might gain standing. Although Lujan represents the Supreme Court's latest word on procedural injuries, other possible ways of gaining procedural standing have also emerged.

\section{A. The Approach to Procedural Injuries in Lujan}

1. The injury in Lujan: a procedural injury.

Lujan involved, a suit brought by environmental organizations alleging violations of the Endangered Species Act of 1973 ("ESA"). ${ }^{31}$ The purpose of the ESA is to protect endangered species from any federal action threatening their existence. ${ }^{32}$ The plaintiffs challenged a rule promulgated by the Secretary of the Interior that interpreted the ESA to apply only in the United States or on the high seas. ${ }^{33}$ Under the rule, the Secretary did not have to consult with federal agencies about the possible impacts on endangered species of their actions in other countries. ${ }^{34}$ The net result of the rule was that federal action abroad that threatened an endangered species would go unchallenged and unchecked.

The Lujan plaintiffs asserted that the rule was an erroneous interpretation of the geographic scope of the ESA. The injury they claimed was procedural: Interior's rule removed a procedural safeguard-consultation-from federal actions abroad that affected endangered species. Without consultation, there was an increased risk that endangered species would perish. As in all procedural injury cases, the redressability requirement stood in the way of standing. The environmental organizations could not show that judicial relief-an order requiring consultation-would

\footnotetext{
right to enforce procedural obligations was invalid because it attempted to grant standing for injuries that were not concrete. See id at 2142-46. The opinion did not address whether all procedural injuries are impermissibly abstract, but the Court's dicta suggested that at least some procedural injuries are cognizable. See id at 2142-43 n 7. For a more detailed discussion, see text accompanying notes 35-45.

31 16 USC $\$ \S 1531$ et seq (1988 \& Supp 1992).

${ }^{32}$ See Lujan, $112 \mathrm{~S}$ Ct at 2135.

${ }^{33}$ See id.

${ }^{34}$ See 50 CFR $\$ 402.01$ (1991).
} 
redress the injury to the environment because the federal agencies might still proceed with their projects as planned even after consulting with the Department of the Interior about possible environmental harms.

2. The test for procedural injuries under Lujan.

The plaintiffs' procedural injury claim in Lujan was based on a "citizen-suit" provision in the ESA, which states that "any person may commence a civil suit on his own behalf [] to enjoin any person, including the United States and any other governmental instrumentality or agency ... who is alleged to be in violation of any provision of this chapter. "35 The Court of Appeals had held that this provision created a "procedural right" in the plaintiffs, "the invasion of which is sufficient to satisfy the requirement of injury in fact in [A]rticle III. ${ }^{\prime 36}$ On this view, a federal agency's violation of procedures is itself an injury-sufficient to satisfy the injury-in-fact requirement of judicial standing-because Congress intended to allow private citizens to challenge such violations in court. ${ }^{37}$

The Supreme Court rejected the Court of Appeals's position, reasoning that granting standing to challenge any procedural lapse would violate the "concreteness" aspect of the injury-in-fact rule. $^{38}$ The Court characterized the procedural right as an "abstract, self-contained, non-instrumental 'right' to have the Executive observe the procedures required by law." ${ }^{339}$ This right, in the Court's view, amounts to the right to vindicate the public interest, and as such it is properly left to the legislative and executive branches rather than the courts. ${ }^{40}$ Unless a plaintiff can identify a concrete harm, establishing that he "himself [has] suffered an injury, ${ }^{\prime 41}$ the plaintiff has not proven injury in fact, and must instead work through the political process if he is to vindicate this interest. In denying the plaintiffs' procedural injury claim as

${ }^{35} 16$ USC $\S 1540$ (g).

${ }^{36}$ Defenders of Wildlife $v$ Lujan, 911 F2d 117, 121 (8th Cir 1990), rev'd, 112 S Ct 2130, quoting Fernandez v Brock, 840 F2d 622, 630 (9th Cir 1988).

${ }^{37}$ See text accompanying notes 65-72 for an elaboration of this position.

${ }^{38}$ See Lujan, 112 S Ct at 2143 ("IA] plaintiff ... claiming only harm to his and every citizen's interest in proper application of the Constitution and laws, and seeking relief that no more directly and tangibly benefits him than it does the public at large [1] does not state an Article III case or controversy.").

${ }_{39}$ Id.

to See id at 2145.

11 Id at 2145-46, quoting Sierra Club v Morton, 405 US 727, 738 (1972). 
too general, the Lujan Court made clear that procedural plaintiffs, like all others, must meet the concrete injury requirement, even if Congress has created a special cause of action based on procedural violations.

Although the Lujan Court denied standing to the plaintiffs, dicta relegated to a footnote suggests that, under certain circumstances, procedural standing would be possible:

There is much truth to the assertion that "procedural rights" are special: The person who has been accorded a procedural right to protect his concrete interests can assert that right without meeting all the normal standards for redressability and immediacy. ${ }^{2}$

This passage suggests that the Court believes that the injury-infact and redressibility requirements should be adjusted for procedural plaintiffs. Under this approach, plaintiffs like the camper would still have to have a "concrete" interest at stake, such as an interest in personally observing an animal species, ${ }^{43}$ but they would not have to show that substantive environmental harm was imminent. The Lujan dicta would also relax the redressability requirement so that someone in the camper's position would not have to show that the preparation of an EIS would definitely prevent the substantive harm.

The plaintiffs in Lujan did not qualify for the reduced redressability standard because they were unable to meet the injury-in-fact requirement: they had no concrete interest at risk. The plaintiffs' interest in observing the endangered species abroad was not concrete, or separable from the general public, because they did not have definite plans to visit the area again. ${ }^{44}$

The approach suggested in Lujan would most benefit those plaintiffs who are able to allege that the lack of procedure threatens their personal interests. For example, the camper who often observes beavers would qualify for the lower imminence and redressability requirements because his frequent use of the threatened area establishes a concrete, nongeneralized interest.

$42112 \mathrm{~S}$ Ct at $2142 \mathrm{n} 7$.

43 The Lujan majority recognized that this kind of aesthetic interest satisfies the injury-in-fact requirement. Id at 2137. According to the Court, the plaintiffs in Lujan had no injury in fact because their plans to observe the species were not "imminent." Id at 2138. If they had been, presumably the aesthetic interests would have been concrete enough to establish standing.

44 Id at 2138-40. 
He can adequately allege that the dam would hinder, if not destroy, his own aesthetic and recreational interests in camping and observing beavers. ${ }^{45}$

Lujan's procedural injury dicta is not without its problems, however. At best, it is vague and provides little guidance for prospective plaintiffs and the lower courts; at worst, it eviscerates the standing requirements of the Constitution. The approach is, in the words of Justice Blackmun, "standardless." After Lujan, the contours of the redressability and injury-in-fact standing requirements in procedural injury cases are unknown. The Court failed to answer whether redressability falls out entirely from the standing inquiry in procedural cases, or whether procedural plaintiffs must show something short of the "normal" standard for redressability. ${ }^{47}$ Even if the Court can constitutionally loosen the redressability requirement, the question of how to apply the requirement remains. The Court suggested that the "normal" standards of redressability need not be met. ${ }^{48}$ The normal requirement is that the plaintiff must show that the relief is likely to redress the injury. Under the Court's suggestion, does "likely" become "possible," or something else? The Court offers no guidance on this point. Similarly, the Court did not make it clear whether it intended completely to abandon the imminence component of the injury-in-fact requirement. ${ }^{49}$ The vagueness of the suggested approach is likely to lead to inconsistencies among the lower courts.

Furthermore, the approach suggested in the Lujan dicta is potentially unconstitutional. The dilution of the redressability requirement for procedural plaintiffs apparently envisions modifying the "core" elements of standing that the Lujan majority declared were "an essential and unchanging part of the case-orcontroversy requirement of Article III," which is itself the "cen-

45 Compare Morton, 405 US at 734-35. There, the Court denied the plaintiffs standing because the plaintiffs did not allege that a proposed skiing development would affect the club or its members, but maintained that the project would adversely change the area's aesthetics and ecology.

${ }^{46}$ Lujan, $112 \mathrm{~S}$ Ct at 2158 (Blackmun dissenting).

47 The Court does not provide guidance on this issue; only three Justices joined Scalia's opinion on the question of redressability. Furthermore, Scalia appeared to retreat from the redressability determination later in the opinion, stating that the Court did not rely upon the argument that the injury was not redressable. Id at $2143 \mathrm{n} 7$.

48 Id.

19 This would be unlikely, given that the Court held that the Defenders of Wildlife had sustained no injury in fact because its members did not have immediate plans to visit the affected areas. See id at $\mathbf{2 1 3 8 .}$ 
tral mechanism of separation of powers." If the standing requirements are truly essential for maintaining the proper separation of powers; then they should not be waived or diluted for procedural plaintiffs. If, on the other hand, redressability really is not an essential part of the Article III case-or-controversy requirement, then it should not be required for standing in any situation-except, perhaps, as a prudential requirement. Not only is redressibility required by the Constitution as interpreted by the Court, but there are also policy reasons for keeping the requirement intact. ${ }^{51}$ Thus, the constitutional importance of the standing requirements counsels against using the approach posited in Lujan.

\section{B. Other Approaches to Procedural Injury}

1. The "normal" standing requirements apply to procedural injury plaintiffs.

One possible alternative to the Lujan approach is simply to retain the constitutional requirements for procedural injuries without modification. Given the Supreme Court's emphasis that these requirements are a "constitutional minimum," and given the rarious policy reasons for retaining them, this solution seems to be the most logical at first glance. It is clear and easy to apply and is apparently constitutional. Because procedural injury plaintiffs cannot meet these "normal" requirements, however, this approach would categorically deny standing to all procedural injury plaintiffs. ${ }^{53}$

Some courts have continued to apply the stringent standing requirements to procedural injury cases even after Lujan. For example, in Pacific Northwest Generating Cooperative $v$ Brown, the District Court for the District of Oregon dutifully applied the "constitutional minimum" standing requirements to plaintiffs' claim that a regulation to improve salmon migration increased

so Id at 2136 (emphasis added).

51 See text accompanying notes 13-18.

${ }^{52}$ Lujan, $112 \mathrm{~S} \mathrm{Ct}$ at 2136.

53 Procedural injury plaintiffs are unable to prove that rectifying procedures will definitely redress the underlying substantive injury. For example, the camper cannot prove that an EIS would eliminate environmental damage, the underlying substantive injury. Although not discussed in this Section, procedural plaintiffs will also have a difficult time satisfying a strict imminence requirement, since the ultimate injury they seek to prevent may not occur for a considerable time. See text accompanying note 27. 
their electric rates. ${ }^{54}$ The suit was brought under the same Endangered Species Act citizen-suit provision involved in Lujan, and the court applied the "normal" redressability standard, denying standing in part because the plaintiffs could not prove redressability. The court held that because other factors could have caused the rate increase, a change in the regulation would not necessarily have reduced their rates. ${ }^{55}$ The approach suggested in Lujan seems to permit a loosening of the redressability requirement such that the plaintiffs here would have had standing. It is possible, though not certain, that repealing the regulation would prevent an increase in rates. The court, however, did not address the Lujan approach.

In Sierra Club $v$ Simkins, the Fourth Circuit purported to apply the normal redressability requirement but did not rigorously enforce it. ${ }^{56}$ Although redressability traditionally requires that the judicial relief be "Tikely" to redress the injury, the court found that imposing civil penalties on a private party who violated environmental reporting requirements redressed the potential environmental injury. ${ }^{57}$ The court imposed the penalties, even though this remedy did not make it "likely" that environmental damage would not occur. ${ }^{58}$ The fined party could always choose to treat the penalty as a cost of polluting, in which case it would inflict environmental harm anyway. The court maintained that it was applying the constitutional requirements, but it actually loosened them in a way that is consistent with the dicta in Lujan. The difference is that the court in Simkins did not explicitly modify the requirements. The problem with the Simkins approach is that it will lead to unpredictable and perhaps improper decisions on when to implicitly depart from the redressability requirement.

Requiring procedural injury plaintiffs to meet the unmodified standing requirements is problematic for two reasons. First, it ignores the Lujan Court's dicta that some procedural injury

54822 F Supp 1479, 1500-01 (D Or 1993).

5s Id at 1502-03.

E6 847 F2d 1109 (4th Cir 1988).

57 Id at 1113.

${ }^{6 S}$ Id. One of the earliest cases to apply the redressability requirement, Linda R.S. $v$ Richard D., 410 US 614 (1973), seems to require a finding of no redressability in Simkins. In Linda R.S., the Court held that prosecuting a father in criminal court for failure to provide child support did not make it likely that the plaintiff (the mother) would receive the child support. Id at 618 . The imposition of civil penalties on a private party, as in Simkins, will have similarly ambiguous consequences, and therefore should not meet the redressability requirement. 
plaintiffs-those with a "separate concrete interest" at stake-should have standing. ${ }^{59}$ Second, strict adherence to the redressability requirement is contrary to sound policy, and effectively defeats Congress's intention to allow litigants to pose legal challenges to the processes causing the damage. ${ }^{60}$ Requiring a rigid concept of redressability would render all procedural injuries noncognizable because plaintiffs cannot prove that following a procedure will remedy an underlying substantive injury. However, procedural injury suits provide a much-needed incentive for agencies to follow mandated procedures; if plaintiffs are denied standing to force agencies to adhere to procedures, the procedures are meaningless.

Requiring redressability would have particularly far-reaching consequences in the administrative law context, where parties frequently challenge agency actions on procedural grounds. In administrative cases, the Court has already granted parties standing for challenges based on the now well-established "procedural" rights to notice, hearing, and adequate consideration of alternatives. For example, in United States $v$ Florida East Coast Railway Co., the Court allowed a regulated railroad to challenge the procedure by which its rates were determined. ${ }^{1}$ The railway claimed that the rates should have been issued after formal rather than informal rule making. ${ }^{62}$ If the Court had enforced the redressability requirement, the railway would not have had standing because the shift to formal procedures did not make it likely that the substantive rate regulation would change. In $\mathrm{Mo}$ tor Vehicles Manufacturers Ass'n v State Farm Mutual Automobile Insurance Co., the Court allowed a challenge to an agency's failure to consider alternative courses of action before making a final decision. ${ }^{63}$ Here, too, strict enforcement of redressability would have precluded standing because ordering mere consideration of alternatives would not have mandated a different substantive result nor made it probable that one would occur. These cases are but two of the many in the area of administrative law granting standing without discussing redressability, which suggests that redressability was understood to have been satisfied in those cases. ${ }^{64}$ These decisions assume that procedural harms, or

\footnotetext{
${ }^{59}$ Lujan, $112 \mathrm{~S}$ Ct at 2142-43 n 7.

6s See text accompanying notes 19-20.

61410 US 224 (1973).

62 Id at 238-39.

63 463 US 29 (1983).

${ }^{64}$ See, for example, United States v Nova Scotia Food Products Corp., 568 F2d 240,
} 
increased risks of substantive harm, are injuries in fact, and that redressability and causation are therefore easily met.

\section{Violations of procedure constitute injuries in fact.}

Prior to the Supreme Court's review of the case, the Eighth Circuit had granted standing to the plaintiffs in Lujan on a different procedural injury theory. ${ }^{65}$ The Court of Appeals reasoned that the citizen-suit provision in the ESA conferred "procedural rights" upon any person who wished to challenge an agency's failure to follow mandated procedures. ${ }^{66}$ Accordingly, when Congress enacted the citizen-suit provision, it "created" a legally cognizable injury in fact-an injury inflicted when an agency does not follow procedures. The Eighth Circuit's opinion did not address the concrete injury requirement, which was the basis of the Supreme Court's subsequent rejection of standing. Instead, the Court of Appeals deferred to the "plain intent" of Congress to grant standing to "any person."

In his dissent in Lujan, Justice Blackmun endorsed the lower court's view of procedural injuries. Blackmun argued that because some procedural duties are "enmeshed" with the prevention of substantive harm, plaintiffs should be able to demonstrate injury in fact "just through the breach of that procedural duty." The problem with this view is that it seems to run afoul of the concrete injury requirement: if any citizen can gain standing simply by alleging a violation of procedure, then the plaintiff's claimed injury is no longer distinct from that of the general public. Thus, the concrete injury requirement disappears if any citizen has standing to allege an agency's procedural error on the basis of a broadly stated statutory cause of action.

The position of the Eighth Circuit and Justice Blackmun-that the citizen-suit provision satisfies the injury-infact requirement-allows Congress to confer standing by enacting statutes that expand the category of cognizable injuries. Although the majority in Lujan recognized that an injury in fact could exist "solely by virtue of 'statutes creating legal rights, the invasion of

252 (2d Cir 1977) (right to disclosure of scientific data on which agency relied); Weyerhaueser Co. v Costle, 590 F2d 1011, 1030 (DC Cir 1978) (right to comment on decision-making process); Union Electric Co. $v$ Federal Energy Regulatory Commission, 890 F2d 1193, 1203 (DC Cir 1989) (right to be heard).

6s Defenders of Wildlife $v$ Lujan, 911 F2d 117, 121-22 (8th Cir 1990).

66 Id at 121.

.67 Id.

63 $112 \mathrm{~S} \mathrm{Ct}$ at 2159 (Blackmun dissenting). 
which creates standing,"'69 it emphasized that "the concrete injury requirement must remain." Unlike the Eighth Circuit and Blackmun, the Lujan majority refused to allow Congress to circumvent Article III merely by creating a cause of action for litigants who have not suffered a concrete injury. ${ }^{71}$ Simply put, the Lujan Court found that it would be unconstitutional for Congress to eliminate the requirement of a concrete injury. ${ }^{72}$

\section{Informational injury as injury in fact.}

The doctrine of "informational injury" has frequently been proffered as a solution to the procedural injury problem. ${ }^{73}$ An informational injury occurs when a procedural failure deprives an interested party of information it needs to comment on a regulation or policy. The theory is that the deprivation of information injures "an organization's ability to disseminate information," and that this injury is judicially cognizable when the "information is essential to the injured organization's activities . . . .774 For example, when the government fails to prepare an EIS and make it publicly available, this deprives interested parties of information they could use to comment on the underlying project. Without the information, certain environmentally dangerous projects might proceed without opposition.

By characterizing the denial of information as a substantive harm, the doctrine of informational injury bypasses the redressability problem of procedural standing. A court order requiring an agency to provide information does redress the organization's inability to inform its members. However, the theory's applicability is limited. First, it applies only to those procedural injuries where the unexecuted procedure would have

69 Id at 2145, quoting Warth $v$ Seldin, 422 US 490, 500 (1975), quoting Linda R.S. $v$ Richard D., 410 US 614, 617 n 3 (1973).

$70112 \mathrm{~S} \mathrm{Ct}$ at 2146.

71 Id at 2145. See also Gladstone Realtors $v$ Village of Bellwood, 441 US 91, 100 (1979), quoting Warth, 422 US at 501 ("In no event, however, may Congress abrogate the Art[icle] III minima: A plaintiff must always have suffered 'a distinct and palpable injury to himself;' that is likely to be redressed if the requested relief is granted.").

$72112 \mathrm{~S} \mathrm{Ct}$ at 2146.

${ }^{73}$ See, for example, Note, Informational Standing under NEPA: Justiciability and the Environmental Decisionmaking Process, 93 Colum L Rev 996 (1993) (arguing that the courts should recognize informational standing in the NEPA context). See also Lujan $v$ National Wildlife Foundation, 497 US 871, 898-99 (1990) (addressing the informational standing argument of the plaintiffs but not deciding the viability of the doctrine).

${ }^{74}$ Competitive Enterprise Institute v National Highway Traffic Safety Administration, 901 F2d 107, 122 (DC Cir 1990). 
provided at least some information. ${ }^{75}$ Most significantly, the doctrine is limited to organizational plaintiffs; the camper will not be able to use the doctrine unless he belongs to an environmental organization willing to sue on his behalf.

In National Organization for the Reform of Marijuana Laws $v$ United States Department of State, the court applied the informational injury theory. ${ }^{76}$ The District Court for the District of Columbia held that the plaintiff ("NORML") had an organizational interest in using an EIS to inform its members about the federal government's marijuana policy. ${ }^{77}$ NORML contended that it needed the EIS to assess the environmental effects of spraying marijuana with herbicides under a federally supported program run by the Mexican government. ${ }^{78}$ The organization further alleged that the government's failure to prepare the EIS had produced an informational injury. ${ }^{79}$

Part of NORML's purpose is to disseminate information to its members about the nation's marijuana policy so that members can use this information to lobby Congress to change the policy. The government's failure to prepare an EIS thus directly hindered NORML's ability to perform its mission, and the court accepted the argument that this failure caused the organization an injury in fact, whether or not an EIS would have changed the spraying policy. ${ }^{80}$

75 There are a fair number of such cases, however. For example, whenever an agency action threatens the environment, plaintiffs suffer an informational injury unless the agency prepares an EIS.

${ }_{76} 452$ F Supp 1226, 1230 (D DC 1978). For more recent cases granting standing on this theory, see National Wildlife Federation $v$ Hodel, 839 F2d 694, 712 (DC Cir 1988) (concluding that "the elimination of the opportunity to see and use an EIS prepared under federal law does constitute a constitutionally sufficient injury on which to ground standing"); Public Citizen v Office of the United States Trade Representative, 822 F Supp 21, 2729 (D DC 1993), rev'd on other grounds, 5 F3d 549 (DC Cir 1993) (granting standing to challenge government's failure to prepare EIS on the North American Free Trade Agreement based on plaintiff's organizational interest in keeping its members informed). Note that informational injury is not limited to EIS cases. For example, Action Alliance of Senior Citizens of Greater Philadelphia $v$ Heckler, 789 F2d 931, 939 (DC Cir 1986), granted plaintiffs standing to challenge agency regulations that eliminated the requirement that federal funding recipients disclose the age distinctions they utilize.

${ }^{77}$ Section $102(2)(C)$ of NEPA provides, "all agencies of the Federal Government shall ... include in every recommendation or report on proposals for legislation and other major federal actions significantly affecting the quality of the human environment, a detailed statement . . . . 42 USC $\$ 4332(2)(C)$.

$78 \quad 452$ F Supp at 1228.

79 NORML also alleged recreational and health injuries, but the court specifically recognized that informational injury was sufficient to establish standing. See id at 1230.

80 Id at 1233. 
After Lujan, some courts have been skeptical of the informational injury doctrine. For example, in Foundation on Economic Trends $v$ Lyng, the D.C. Circuit expressed concern that allowing standing for informational injuries "would potentially eliminate any standing requirement in NEPA cases": an organization would need only allege that it required the information to carry out its purpose of informing its members about environmental matters. ${ }^{81}$ The court was also concerned that recognizing informational injuries would confer standing upon parties with "a mere interest in the problem." ${ }^{82}$ Finally, the D.C. Circuit was worried that recognizing informational injuries could potentially allow individual plaintiffs into court on the theory that NEPA protected the public's right to information. ${ }^{83}$

The Eleventh Circuit, also skeptical of whether informational injuries survived Lujan, stated flatly in Region 8 Forest Service Timber Purchasers Council $v$ Alcock that informational injuries are "nothing more than generalized grievances which fail to satisfy the injury-in-fact requirement for standing." ${ }^{.84}$ Under this interpretation, an interest in gaining information is an interest common to all citizens, and therefore too general to be the basis of standing. The court recognized, however, that under Lujan, plaintiffs do have standing when they can demonstrate an injury to a separate, concrete interest. ${ }^{85}$

The informational injury characterization is not a boon to procedural plaintiffs. First, it applies only to a subset of injuries; it cannot universally solve the procedural injury standing problems. Second, the doctrine does not help an individual escape the concrete injury requirement. Standing on the basis of an informational injury is available only to organizations, and an organization has standing only when at least one of its members would have standing to sue in his own right. ${ }^{86}$ Therefore, individual procedural plaintiffs receive no benefit from informational injury theory because they still must show a concrete injury in fact even if their organization alleges an informational injury.

81 943 F2d 79, 84 (DC Cir 1991).

82 Id at 84-85, quoting Sierra Club v Morton, 405 US 727, 739 (1972) (emphasis added). This concern echoes Lujan's declaration that litigants have no standing to vindicate generalized interests because such interests are not concrete. See Lujan, $112 \mathrm{~S} \mathrm{Ct}$ at 2143-46.

83 Foundation on Economic Trends, 943 F2d at 85.

${ }^{84} 993$ F2d 800, 810 (11th Cir 1993).

s5 Id.

${ }^{86}$ See Competitive Enterprise Institute, 901 F2d at 111. 
Furthermore, if informational standing allows organizations to gain standing without a concrete interest, it appears to violate the concrete injury requirement of Article III. Interests in receiving information are noncognizable general grievances that anyone can allege, unless an organization member has a concrete interest at stake. ${ }^{87}$ According to the Lujan Court, such ideological concerns are better resolved through the legislative process. ${ }^{88}$ When, however, a member has a concrete interest, which the provision of information will help protect, the organization will be able to challenge agency actions on an information theory. ${ }^{89}$

\section{AN Alternate Approach to Procedural InJury Claims}

If procedural injury plaintiffs must meet the "normal" standing requirements, they will never be permitted to voice their claims in court. As discussed above, courts have approached this problem in several ways. Of those, recharacterizing the procedural injuries as informational injuries appears the most promising because it solves the redressability and causation problems not by waiving or modifying the "normal" standing requirements, but by viewing procedural plaintiffs' injuries as present injuries that are redressable through adherence to mandated procedures.

However, a significant drawback of the informational injury approach is that it does not eliminate the problem of proving a concrete injury. Characterizing a deprivation of information as the "cause" of the injury, and the provision of the information as "redressing" the injury, does not distinguish the plaintiff's injury from an injury to the general public. So, recharacterization only addresses the redressability and causation problems. An im-

87 One response to this criticism of informational injury is that if informational injuries are not concrete, then Freedom of Information Act ("FOIA") requests are not judicially enforceable. See Richard J. Pierce, Jr., Lujan v. Defenders of Wildlife: Standing as a Judicially Imposed Limit on Legislative Power, 42 Duke L J 1170, 1189 (1993). However, the Freedom of Information Act response is inapposite. The reason informational injuries in the FOIA context are concrete is that Congress limited standing to those who requested information and were denied. 5 USC $\S 552(a)(4)(B)(1988)$. In contrast, the citizen-suit provision in Lujan granted standing to "any person," without qualification. 16 USC $\S$ 1540 (g). Standing in FOIA cases is consistent with Justice Kennedy's concurrence in Lujan, which argued that Congress can meet the concrete injury requirement as long as it "identiffies] the injury it seeks to vindicate and relate[s] the injury to the class of persons entitled to bring suit." $112 \mathrm{~S} \mathrm{Ct}$ at 2147 (Kennedy concurring).

s8 Id at 2145 .

69 Under Lujan, a plaintiff can demonstrate a concrete injury only by showing active use of an area or an imminent plan to visit the area. See $112 \mathrm{~S} \mathrm{Ct}$ at 2138-40. 
proved solution would recognize Lujan's emphasis on the importance of the constitutional requirements, but also require procedural injury plaintiffs to show that the underlying substantive injury affects their own concrete interests.

A. Congressional Elimination of the Redressability Requirement

One solution to the procedural injury dilemma is for Congress to enact legislation that establishes causation and redressability automatically for procedural plaintiffs, thereby removing the need for courts to address these issues. ${ }^{90}$ Although Congress cannot eliminate the injury-in-fact requirement, under this theory it can eliminate, or at least overcome, the other two prongs of the constitutional standing requirements. Congress could create a citizen-suit provision mandating that an agency's failure to follow procedures "causes" an injury to those with an underlying substantive interest, and that adherence to procedures is sufficient to "redress" a procedural plaintiff's injuries. This view is arguably consistent with the Lujan dicta, which appeared to waive the causation and redressability requirements for plaintiffs who "[have] been accorded a procedural right...." ${ }^{\prime 91}$ This suggests that when Congress creates citizen suits, it confers procedural rights that bypass the strict redressability requirement.

One of the problems with this approach is that it applies only to a subset of injuries-those cases where Congress has enacted a citizen-suit provision, or where the legislative history contains findings of causation or redressability. ${ }^{92}$ A second problem is that congressional modification of the constitutional standing requirements plunges headlong into separation-of-powers problems. If the requirements are truly "essential" under Article III-as Lujan indicates they are-then Congress and the courts cannot modify them. The courts, and not Congress, should announce and apply the standing requirements because they have the final word on constitutional interpretation..$^{93}$

90 See Sunstein, 91 Mich L Rev at 229-30 (cited in note 9); see generally Comment, Standing on Firmer Ground: Separation of Powers and Deference to Congressional Findings in the Standing Analysis, 59 U Chi L Rev 1645 (1992).

${ }^{91}$ Lujan, $112 \mathrm{~S} \mathrm{Ct}$ at $2142 \mathrm{n} 7$.

${ }^{92}$ See Comment, $59 \mathrm{U}$ Chi L Rev at 1663 (arguing that Congress is better equipped than the courts to make the causation and redressability determinations).

${ }^{93}$ Marbury $v$ Madison, 5 US (1 Cranch) 137 (1803). 
B. Recharacterizing the Injury

This Comment proposes that in order to meet these goals, a court should proceed as follows. First, it should characterize an agency's failure to adhere to procedural requirements as an injury in fact to a plaintiff if the failure increases the risk of future substantive harm. Second, the court should examine the underlying interest protected by the procedure and determine whether it is a concrete, nongeneralized interest. This proposal remains faithful to the constitutional standing requirements, and it will permit courts to confer standing on many, but not all, procedural injury plaintiffs.

The first step of this approach draws its inspiration from the affirmative action context, where many courts have granted standing for procedural injuries by recharacterizing them in a way that meets the injury-in-fact requirement. In Regents of the University of California $v$ Bakke, the Supreme Court recharacterized harm to opportunity, or an increased risk of future harm, as an injury in fact. ${ }^{94}$

In Bakke, the Court upheld the conferral of standing on a twice-rejected nonminority medical school applicant who wanted to challenge the school's admissions policy, which set aside sixteen of one hundred spaces for minorities. In explaining the lower court's theory of standing, the Court held that the relevant injury was not the applicant's failure to be admitted, instead recharacterizing the injury as the denial of equal treatment. ${ }^{95}$

Following Bakke's lead, several recent cases have used recharacterization to grant standing to persons or groups challenging affirmative action plans. In Northeastern Chapter of Associated General Contractors of America $v$ City of Jacksonville, the Court granted standing to a nonminority contractor challenging an affirmative action policy used in the awarding of city contracts. ${ }^{96}$ The alleged injury was procedural in that the policy made it more likely that the plaintiff would be denied a contract on the basis of race. The Court granted standing by characterizing the injury as a failure to be treated equally, ${ }^{97}$ an injury to the plaintiff's opportunity to compete. In Brunet $v$ City of Columbus, the Sixth Circuit similarly granted standing to a group of men applying for fire department positions who wanted to chal-

\footnotetext{
438 US 265 (1978).

95 Id at 281 n 14.

96 113 S Ct 2297, 2304-05 (1993).

97 See id at 2302-03.
} 
lenge an affirmative action policy for female applicants. ${ }^{98}$ Both cases relied on Bakke's holding that the denial of equal treatment is a sufficient injury for standing purposes. ${ }^{99}$

In the above cases, recharacterizing the alleged injuries enabled the plaintiffs to satisfy the standing requirement of redressability. The plaintiff in Bakke could not have shown that a change in admissions policy would definitely cause him to be admitted, just as the plaintiff in Associated General Contractors could not have proved that equal treatment would guarantee that he would get a contract. However, these parties were able to prove that equal treatment would indeed redress their recharacterized injuries-injuries to opportunity-thereby fulfilling the redressability requirement.

These cases suggest that the Court will recognize the claims of procedural injury plaintiffs if they satisfy the redressability criteria by recharacterizing their injuries as injuries to opportunity. For example, the plaintiff organization in Lujan could have characterized its injury as a decreased opportunity to view the endangered species, just as the harm in Bakke was to the plaintiff's opportunity to attend medical school. ${ }^{100}$ In fact, all procedural plaintiffs should be able to benefit from this strategy: because procedural injuries are by definition increased risks of future injury, they decrease plaintiffs' opportunities to be free from that future injury. Because adherence to procedure rectifies these increased risks of harm, recharacterization satisfies the redressability requirement, thus precluding the need to waive redressability as the Lujan dicta suggested.

However, recharacterization alone cannot overcome the concrete injury difficulty in the procedural injury context. No matter how the injury is depicted, the harm must still occur to a discrete individual or group; it cannot be the same as the harm suffered by the public at large. Thus, a court should require that all procedural plaintiffs who are able to recharacterize their injuries and fulfill the redressability criteria still show that the threatened future injury is concrete. ${ }^{101}$

${ }_{98} 1$ F3d 390, 398 (6th Cir 1993).

99 Associated General Contractors, $113 \mathrm{~S} \mathrm{Ct}$ at 2302-03; Brunet, 1 F3d at 396-97.

${ }_{100}$ See Sunstein, 91 Mich L Rev at 203-05 (cited in note 9).

${ }_{101}$ The Associated General Contractors plaintiff was able to meet the concreteness requirement easily: the only people affected by the city policy were nonminority contractors in the area-a discrete group. The injury in Bakke was also concrete because a discrete group of people had been denied admittance to the medical school. 
For procedural injuries, the standing inquiry would turn on whether the underlying interest protected by the procedure is concrete, not on whether the failure to follow the procedure is itself an individual injury to the plaintiff. ${ }^{102}$ In order for a risk of injury to be concrete, the interest at risk must be concrete. Thus, a procedural failure that places a concrete interest at risk can form the basis of standing, even though procedural shortcomings alone might not inflict concrete harm. For example, the agency's failure to prepare an EIS places at risk a concrete interest of the camper-his interest in using the threatened area. If, instead of a camper, the plaintiff were a concerned citizen who had never visited the threatened area, the procedural flaw would not be an injury in fact. This result is consistent with the dicta in Lujan, which states that when a procedure exists "to protect [a] concrete interest," the redressability and causation requirements are relaxed. ${ }^{103}$ For procedural injuries, the concreteness inquiry focuses on the interest protected by the procedures, not the interest in procedural integrity for its own sake.

Because this proposal retains the concrete injury requirement, it is consistent with Lujan and would not change the result of the case. The Lujan plaintiffs would not have had standing even if they recharacterized their injury because they had no concrete interest at risk. The organization's members had no imminent plans to visit the environmentally affected area, ${ }^{104}$ and thus were unable to demonstrate an injury distinguishable from that suffered by the general public when environmental damage occurs far away. Even though they would be able to meet the redressability requirement, they would not get standing under this proposal because their underlying substantive injury was not concrete. In contrast, the camper would have standing because he does have an underlying concrete interest-his own personal camping and observation interests.

Other approaches to procedural injury, such as the Eighth Circuit's approach in Lujan, attempt to create new injuries in fact, or new concrete injuries, in order to broaden standing. However, it is no longer viable after Lujan to argue that procedural

102 If the standing inquiry looked to whether the procedural violation was itself a concrete injury, procedural plaintiffs would never have standing because "every citizen's interest in [the] proper application of the Constitution and laws" is not a concrete interest. Lujan, $112 \mathrm{~S} \mathrm{Ct}$ at 2143 . The recommended approach is subtly different-if the procedural violation increases the risk of concrete harm, plaintiffs have standing.

${ }^{103}$ Id at $2142 \mathrm{n} 7$.

${ }^{104}$ See id at 2138 . 
violations are themselves concrete simply due to a legislatively enacted citizen-suit provision. Congress cannot circumvent the constitutional injury-in-fact requirement. In contrast, the approach suggested here does not seek to resolve the concreteness problem by expanding the category of interests deemed concrete; instead it urges that risks to concrete interests be deemed cognizable injuries in fact.

This approach departs from the Lujan dicta by retaining the redressability requirement-a standing requirement with as firm a basis in the Constitution as the injury-in-fact requirement. But by characterizing procedural injuries as injuries to opportunity, the new approach causes the redressability problem to disappear; injuries to opportunity are always redressed by an order to follow the very procedures designed to protect that opportunity. Characterizing injuries as risks of harm upholds the redressability requirement the Court views as an "irreducible constitutional minimum" for standing. ${ }^{105}$ Thus, this approach is consistent with both the body of the Lujan opinion, which emphasized the importance of the constitutional requirements, and with its dicta, which required that plaintiffs have a concrete interest at stake.

An approach following the dicta in Lujan alone would be suspect because the footnote modifies the constitutional requirements. The plaintiff had no concrete interest, so there was no need to apply the redressability requirement, much less to loosen it. In the end, though, the tests may be the same in practice, depending on how little redressability a procedural plaintiff must show under the Lujan dicta. Whether the redressability requirement is waived or whether the injury is characterized such that it is deemed redressable will make little difference to litigants.

The superiority of the recharacterization approach is that it is faithful to Lujan's view of the Constitution. The proposed approach is also preferable because it is precise and easy to apply. The approach to redressability suggested in Lujan is basically standardless (except that "normal" redressability need not be shown), which prevents parties from developing accurate expectations and could potentially lead to conflict among courts attempting to apply it. 


\section{CONCLUSION}

Claims of procedural injury are a major subject of administrative law. In Lujan, the Supreme Court suggested a test for evaluating whether plaintiffs who mount procedural challenges have standing. Along the way, the Court overrode Congress's intent on the standing issue by holding that a statutory grant of citizen standing was unconstitutional, and refused to recognize an environmental injury in parties not planning to visit the actual site of the environmental damage. Although these are legitimate criticisms of the Lujan opinion, they do not assist the lower courts and future procedural plaintiffs in deciphering the ground rules of standing litigation.

Given Lujan, the best approach to procedural injury is to recognize harms to opportunity as real harms so long as the underlying interest to be protected is concrete. This approach has the advantages of preserving the constitutional standing requirements and of providing a straightforward, predictable standing determination. Under this approach, future standing battles will be fought over whether injuries are concrete, not over the appropriate characterization of injuries, and the law of standing will slowly evolve as the Court recognizes interests as concrete. Just as injuries resulting from dirty air or depleted animal species have only recently become cognizable, perhaps the Court might one day recognize as concrete the environmental interests of concerned citizens who do not live near or plan to visit a threatened area. Until then, environmentalists and all procedural plaintiffs are bound by current conceptions of injury. 


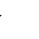

